\title{
LRMSC Grade 2, Subcutaneous Tissue
}

National Cancer Institute

\section{Source}

National Cancer Institute. LRMSC Grade 2, Subcutaneous Tissue. NCI Thesaurus. Code C121177.

Moderate fibrosis but asymptomatic; slight field contracture; $10 \%$ linear reduction. 